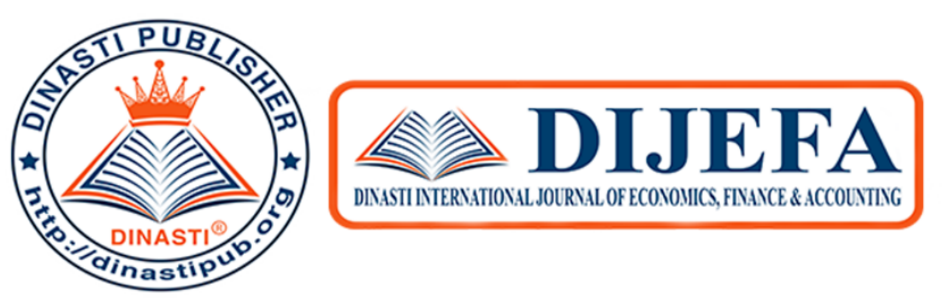

+62 81387654578

+6281387654578

https://dinastipub.org/DIJEFA(-)

dinasti-info@gmail.com @.

\title{
DETERMINATION OF CONSUMER LOYALTY THROUGH CUSTOMER SATISFACTION
}

Renil Septiano"), Laynita Sari ${ }^{2)}$

${ }^{1,2)}$ STIE KBP, West Sumatera, Indonesia

\section{ARTICLE INFORMATION \\ Received: 28 September 2020 \\ Revised: 20 October 2020 \\ Issued: 01 December 2020 \\ Corresponding author: First \\ Author \\ Email: \\ 1) renil.septiano@gmail.com \\ 2)laynitasari4@gmail.com}

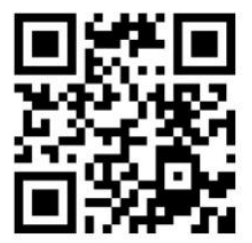

DOI: $10.38035 / D I J E F A$
Abstract: Customer satisfaction causes customers to be loyal so that the company can maintain a sustainable competitive advantage. This study aims to determine the impact of brand image, price perception, perceived value on consumer loyalty through customer satisfaction at Rayhan Toko Muslim in the city of Padang. The research method used is associative, with descriptive and verification data disclosure. The population is the consumer of Rayhan Toko Muslim in the city of Padang. Data collection through a survey of 203 respondents. The analysis technique used is path analysis. The results showed that: brand image, perceived price, perceived value, and customer satisfaction had a significant effect on consumer loyalty. All of them have an influence in a positive direction, except for the price perception variable. The management of Rayhan Toko Muslim, pay attention to things that can increase customer loyalty, so that business continuity can be maintained.

Keywords: Brand, Price, Value, Satisfaction, Loyalty

\section{INTRODUCTION}

To protect their citizens, many countries have implemented rules to prevent the spread of the Covid-19 virus in their countries, including Indonesia. In Indonesia, the government enforces a rule called PSBB (Large-Scale Social Restrictions). This restriction aims to limit the movement of the population so that they can avoid transmission of the covid-19 virus. On the other hand, the restrictions imposed also have an impact on the economy. Many business actors cannot carry out their business as usual, as is the case with consumers. Consumer movement is limited, in order to avoid the spread of the Covid-19 virus. The economic sector is experiencing a slowdown and even a decline in some countries. Not much different from what happened in 
Indonesia, the economic rate was also affected. The effects of the economic slowdown were felt in all sectors, from large to small ones.

Rayhan Toko Muslim, a shop that sells clothes located in Padang Utara District, Padang City, West Sumatra Province, was also affected by the economic slowdown that occurred. Rayhan Toko Muslim provides the needs of customers who need clothing. Not only Rayhan Toko Muslim, in the city of Padang there are several shops or similar businesses that sell the same type of product, so it can be said that there is competition for business in this field. This competition can be seen from the increasing number of the same types of businesses offering programs whether in the form of price reductions or discounts, or other programs to support sales, especially during times of economic sluggishness due to the Covid-19 pandemic. Including how to provide customer needs in terms of service. This makes similar businesses compete to be more creative and innovative in selling their products, which in this case is clothing sales services in order to be superior to its competitors.

Every shop or other type of business strives for a prominent position in the market rather than accepting a bottom position. Shops also had to expand their offering mix in an effort to gain customer share and not just market share. Every business must win in a changing market, and see marketing as: dealing with the customers, which requires companies to dynamically and intensively interact with the market (Hasan, 2009).

With so many choices available customers tend to choose the offer that best fits their individual needs and expectations. They buy based on their value viewpoint, so it's no wonder that today's superior companies are those that succeed in satisfying their customers. Understanding consumers in service really determines the company's trust that will be created in relation to the clothing sales business in the city of Padang, which is the object of the author's research, is one of the shops that serves users of clothing sales services, especially Muslim clothing. In business activities, shops are faced with intense competition with similar companies. The large number of similar businesses causes each business actor to undertake or strive to gain even greater market share.

Likewise, Rayhan Toko Muslim, to anticipate market competition, must be able to see what influences consumers when shopping. Especially in the months when consumers have an increased need for Muslim clothing, for example in the month of Ramadan. From the data it can be seen that there was an increase in sales in May, because the month coincided with the month of Ramadan and before the Eid Al-Fitr. It can be understood that to worship, especially in a month full of virtue, consumers also want to worship in the best or newest clothes. Rayhan Toko Muslim sales data in Q2 2020 can be seen in the following table: 
Table 1.Q2 sales in 2020

\begin{tabular}{|c|r|r|r|}
\hline Brand & \multicolumn{1}{|c|}{ April } & \multicolumn{1}{|c|}{ May } & \multicolumn{1}{|c|}{ June } \\
\hline "SMS" & 44 & 60 & 16 \\
\hline "WM" & 8 & 16 & 7 \\
\hline "OTD" & 6 & 10 & 4 \\
\hline "KRM" & 0 & 2 & 2 \\
\hline Other & 9 & 12 & 7 \\
\hline Total & 69 & 100 & 34 \\
\hline
\end{tabular}

\section{LITERATURE REVIEW}

Marketing is about identifying and meeting human and social needs, one of the best shortest definitions of marketing is meeting needs profitably (Kotler \& Keller, 2016). Marketing is essentially a creative corporate activity involving the planning and execution of the conception, pricing, promotion and distribution of ideas, product and service in an exchange that not only satisfies customers current needs but also anticipates and creates their future needs at a profit (Kotabe \& Murray, 2004). Marketing is a process of planning and executing the concept, pricing, promotion, and distribution of ideas, goods and services to create exchanges that satisfy individual and organizational goals (Lamb et al., 2011). It can be concluded that: marketing is a social and managerial process where individuals and groups get what they need and want by creating and exchanging products and values with other parties.

\section{Marketing Management}

Management affects the rate, timing and composition of demand to help the company achieve its goals. Marketing management is analysis, build and maintain beneficial exchange with target buyers for the purpose of achieving organizational objectives (Kotler, Philip \& Amstrong, 2006). Marketing management is the analysis, planning, implementation and control of programs designed to create, build and maintain profitable exchanges with target markets, with a view to achieving organizational goals (Saladin \& Oesman, 2003). Marketing management is the analysis, planning, implementation and control of marketing decisions in the area of product offering, distribution, promotion and pricing (Bernhard, 2006). Marketing management is the process of analyzing, planning, organizing, controlling programs that include conceptualization, pricing, promotion and distribution of products, services and ideas designed to create and maintain profitable exchanges with target markets to achieve company goals (Boyd \& Lareche, 2000). It can be concluded that marketing management is the process 
of planning, grouping, implementing and supervising planned programs with the aim of creating the desired exchange with the target market in order to achieve organizational goals.

\section{Consumer Behaviour}

The term consumer behavior is defined as the behavior that customers display in searching for, purchasing, using, evaluating and disposing of products and services that they expect will satisfy their needs (Schiffman \& Kanuk, 2004). An action concept that studies how individuals, groups, and organizations choose, buy and use products or services that can provide satisfaction, needs and wants, satisfied consumers will be loyal to the goods or services (Engel et al., 2001).

\section{Brand, Price, Value, Trust and Customer Satisfaction}

The brand is a seller's promise to consistently provide certain features, benefits and services to buyers, not just a symbol that differentiates a particular company's product from its competitors. Brand awareness relates to the possibility that the brand name will stick in the mind and the convenience it provides. Meanwhile, brand image is defined as the perception of a brand as shown by the brand association that is owned in the memory of consumers (Kotler, P. and Keller, 2006).

Price perception deals with how price information is fully understood and provides deep meaning to consumers. Price perception becomes a consumer's assessment of the comparison of the amount of sacrifice with what will be obtained from products and services (Zeithaml, 1988).

Value is the terminal and instrument or goal to which behavior is directed, and the goal of achieving that goal (Engel et al., 2001). Value is a relative preference (comparative, personal and situational) which characterizes one's experience in interacting with several objects (Barnes, 2003). There is an influence between value, loyalty and profit. The higher the perceived value the higher the customer loyalty and profit. Perceived value is based on consumer evaluations of products and services. Consumers emphasize that the benefits received from a product or service are the most important component in value. Value is also the quality that consumers receive according to the price paid (Zeithaml, 1988).

Trust is related to emotional bonding, namely the ability of a person to entrust a company or brand to perform or carry out a function (Zikmund, 2003). The trust factor in a brand is a crucial aspect in the formation of loyalty, because it is the willingness of consumers to trust or rely on a product / service in a risk situation because of the expectation that the product / service in question will give positive results (Lau \& Lee, 1999). Customer trust is the customer's response to evaluating the perceived mismatch between expectations and the actual performance of the product in its users. Customer trust is an after-sale evaluation where the alternatives chosen are at least equal to or exceeding customer expectations (Tjiptono, 2008). 
Satisfaction is the result that buyers perceive of company performance that meets their expectations. Customers are satisfied when their expectations are met and happy when their expectations exceed their expectations. Consumer satisfaction is the feeling of someone who is satisfied or vice versa after comparing the reality and expectations received from a product or service (Kotler, P. and Keller, 2006). Consumers base their expectations on the information they receive about the product. If the reality they get turns out to be different from what they expected, then they feel dissatisfied. When the product meets expectations, they will be satisfied (Simamora, 2002). Many benefits received by the company by achieving a high level of customer satisfaction. A high level of customer satisfaction can increase customer loyalty and prevent customer turnover, reduce customer sensitivity to prices, reduce marketing failure costs, reduce operating costs caused by increasing customer numbers, increase advertising effectiveness, and improve business reputation.

Loyalty leads to behavior rather than attitude and a loyal customer will show purchasing behavior which can be interpreted as a regular and long time buying pattern, carried out by units of decision making or decision making. The aspects that affect loyalty are: (1) Satisfaction (2) Emotional bonding. (3) Trust (trust). (4) Experience with the company (history with the company). (5) Ease (choice reduction and habit) (Griffin, 2002).

\section{RESEARCH METHODS}

The research method used is associative, with descriptive and verification data disclosure. Descriptive method : A problem formulation relating to the question of the existence of an independent variable, either only in one or more variables (independent variables are independent variables, not independent variables, because the independent variable is always paired with the dependent variable). Method of verification: "The method of research through evidence to test the hypothesis is the result of descriptive research with statistical calculations in order to obtain the evidentiary results that show the hypothesis is rejected or accepted (Sugiyono, 2019).

The data analysis method used in this study is path analysis. Path analysis is a multivariate data analysis method with the aim of knowing the direct and indirect effects of several causal (exogenous) variables on endogenous (effect) variables with a recursive pattern and all variables can be observed directly. Recursive means that the relationship between variables is one-way, there is no reciprocal relationship. If it is stated that A causes B, then B cannot cause A (Hapzi Ali. Nandan Limakrisna, 2013).

The population of this study were consumers of Rayhan Toko Muslim, who had made purchases during Semester I of 2020. Population is a generalization area consisting of: objects or subjects that have certain qualities and characteristics that are determined by the researcher to be studied and then draw conclusions (Sugiyono, 2019).

Researchers used purposive sampling. Purposive sampling is a technique for determining research samples with certain considerations in order to make the data obtained more 
representative (Sugiyono, 2019). The author uses data for the last 3 months, April, May, June with 203 sales. These three months cover the usual circumstances and conditions of increased sales during Ramadan and Idul Fitri.

Primary data obtained from distributing questionnaires for each variable in this study were measured using a Likert scale where answers were scored using a 5 (five) point Likert scale (Sekaran \& Bougie, 2011).

Table 2. Operationalization of Research Variables

\begin{tabular}{|c|c|c|c|c|}
\hline $\begin{array}{c}\text { VARIABLE } \\
\text { S }\end{array}$ & $\begin{array}{l}\text { VARIABLE } \\
\text { S CONCEPT }\end{array}$ & DIMENSIONS & INDICATOR & SCALE \\
\hline $\begin{array}{c}\text { Brand Image } \\
\qquad\left(\mathrm{X}_{1}\right)\end{array}$ & $\begin{array}{l}\text { Brand image } \\
\text { describes the } \\
\text { extrinsic } \\
\text { properties of } \\
\text { the product } \\
\text { or service, } \\
\text { including the } \\
\text { ways in } \\
\text { which the } \\
\text { brand } \\
\text { attempts to } \\
\text { meet } \\
\text { customers' } \\
\text { psychologica } \\
\text { l or social } \\
\text { needs. } \\
\text { (Kotler \& } \\
\text { Keller, 2016) }\end{array}$ & $\begin{array}{ll}1 & \text { Brand Identity } \\
\cdot & \\
\cdot & \text { Brand Personality } \\
3 & \\
\cdot & \text { Brand Association } \\
4 & \text { Brand Attitude and } \\
\cdot & \text { behaviour } \\
5 & \text { Brand benefit and } \\
& \text { Competence } \\
\end{array}$ & $\begin{array}{l}\text { The product's } \\
\text { physical identity } \\
\text { - } \begin{array}{l}\text { The distinctive } \\
\text { character of a brand }\end{array} \\
\text { The uniqueness of a } \\
\text { product } \\
\text { Brand interactions } \\
\text { with customers } \\
\text { The values and } \\
\text { advantages of a brand }\end{array}$ & $\begin{array}{l}\text { Ordinal } \\
\text { Ordinal } \\
\text { Ordinal } \\
\text { Ordinal }\end{array}$ \\
\hline $\begin{array}{c}\text { Price } \\
\text { Perception } \\
\text { (X2) }\end{array}$ & $\begin{array}{l}\text { Price } \\
\text { perception is } \\
\text { the value } \\
\text { contained in } \\
\text { a given price } \\
\text { relating to } \\
\text { benefits and } \\
\text { owning or } \\
\text { using a } \\
\text { product or } \\
\text { service } \\
\text { (Kotler and } \\
\text { Armstrong, } \\
\text { 2008)" }\end{array}$ & $\begin{array}{l}1 \text { Prices are decent } \\
\text { - and affordable } \\
\text { Prices are in } \\
2 \begin{array}{l}\text { accordance with } \\
\text { the benefits } \\
\text { received by } \\
\text { consumers }\end{array}\end{array}$ & $\begin{array}{l}\text { Affordable prices } \\
\text { - According to the } \\
\text { service to be received } \\
\text { According to the } \\
\text { facilities to be } \\
\text { received }\end{array}$ & Ordinal \\
\hline
\end{tabular}




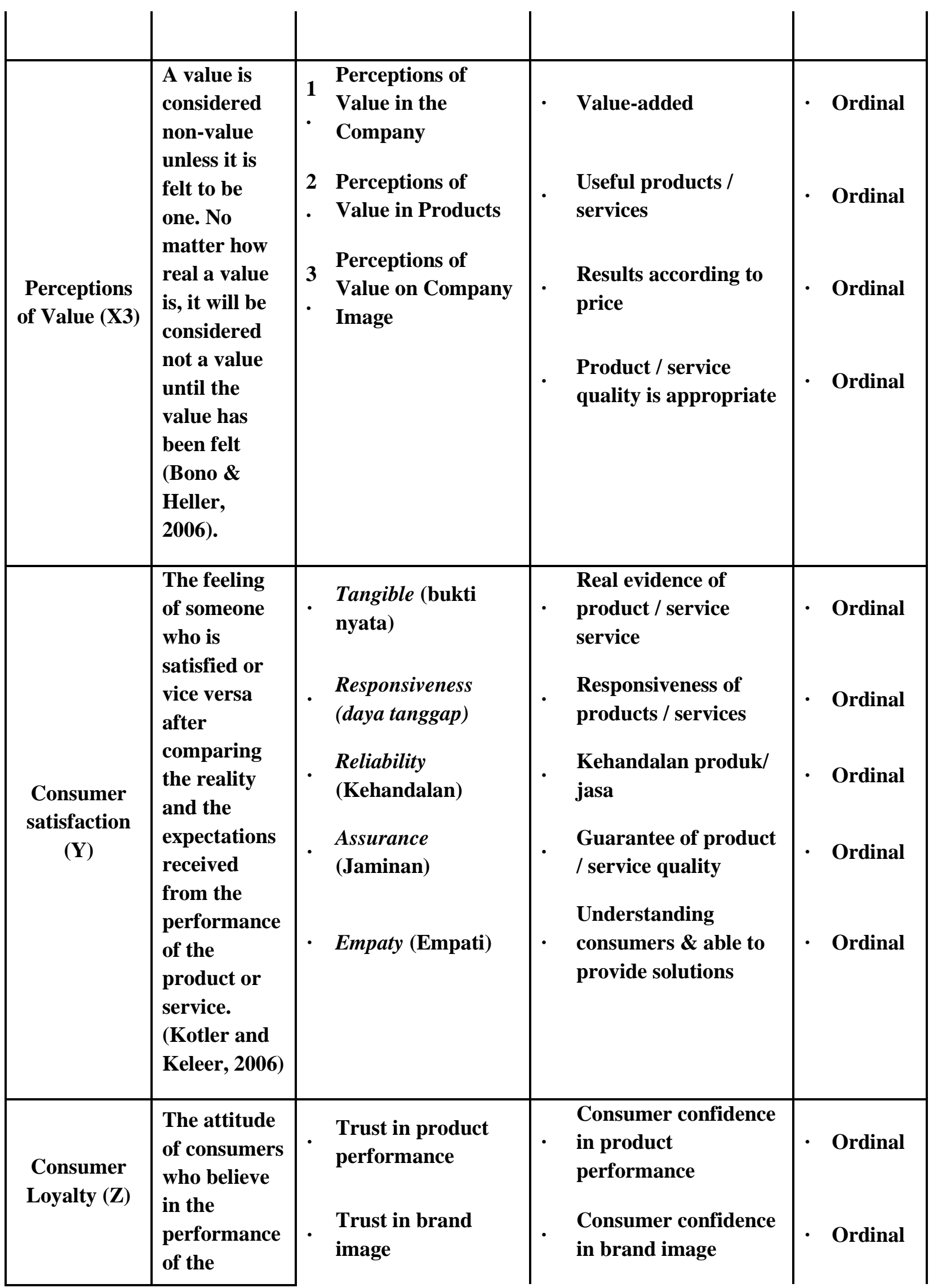




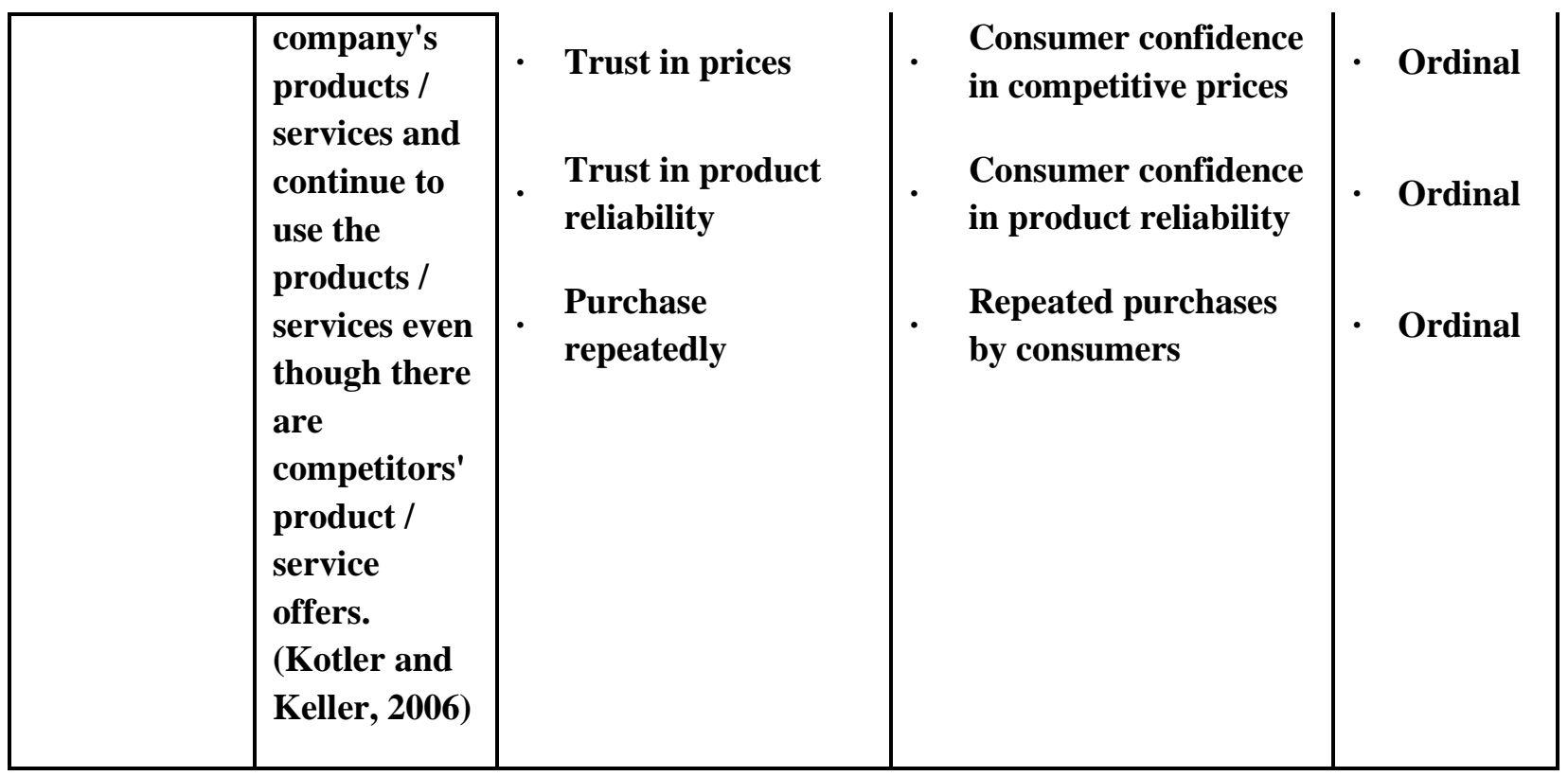

Data processing uses the Amos Amos 21.0.0 program, which is a program package to perform statistical analysis, and to analyze the indirect effect it will be added with the Sobel Test. Sobel test is conducted to test the indirect effect of the $\mathrm{X}$ to $\mathrm{Y}$ variables through $\mathrm{M}$ (Ghozali, 2018).

This study will analyze the direct and indirect effects with a hypothetical model as follows:

Figure 1. Hypothesis Structural Model

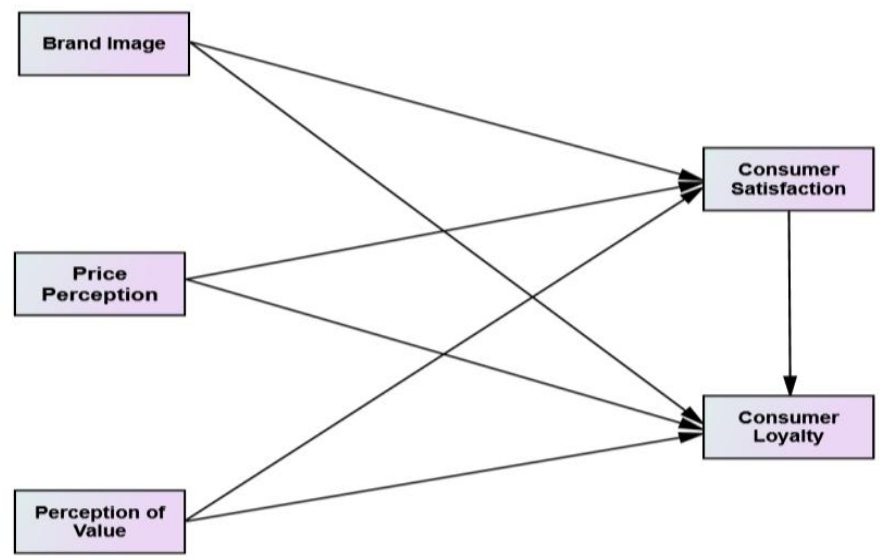

Based on the image above, we can formulate a general hypothesis that will be proposed in the path analysis, namely "Brand Image (X1), Price Perception (X2) and Value Perception (X3) on Customer Satisfaction (Y) and their impact on Customer Loyalty (Z )".

\section{FINDINGS AND DISCUSSION}




\section{Calculating Line Coefficient}

The results of the survey used a questionnaire, processed using Amos 21.0.0 according to the hypothetical framework, the following results were obtained:

Figure 2. the results of data processing using Amos (unstandardized)

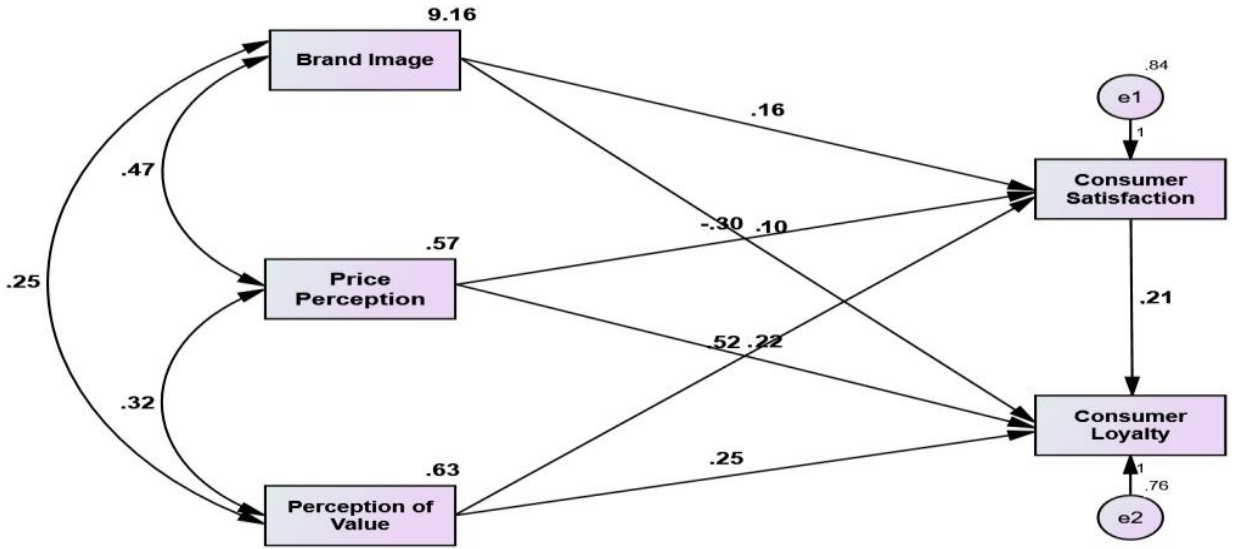

Table 3. Regression Weight

\begin{tabular}{|ll|rrrrl|}
\hline & & Estimate & S.E. & C.R. & P & Label \\
\hline CS <--- & BI & .157 & .022 & 7.205 & $* * *$ & par_1 \\
CS <--- & PP & -.302 & .103 & -2.927 & .003 & par_3 \\
CS <--- & PV & .516 & .096 & 5.373 & $* * *$ & par_5 \\
CL <--- & BI & .098 & .023 & 4.229 & $* * *$ & par_2 \\
CL <--- & PP & .223 & .100 & 2.224 & .026 & par_4 \\
CL <--- & PV & .250 & .098 & 2.562 & .010 & par_6 \\
CL <--- & CS & .205 & .067 & 3.067 & .002 & par_10 \\
\hline
\end{tabular}

BI (Brand Image), PP (Price Perception), PV (Perception of Value), CS (Consumer satisfaction), CL (Consumer Loyalty)

Table 4. Squared Multiple Correlations

\begin{tabular}{|l|l|}
\hline & Estimate \\
\hline
\end{tabular}




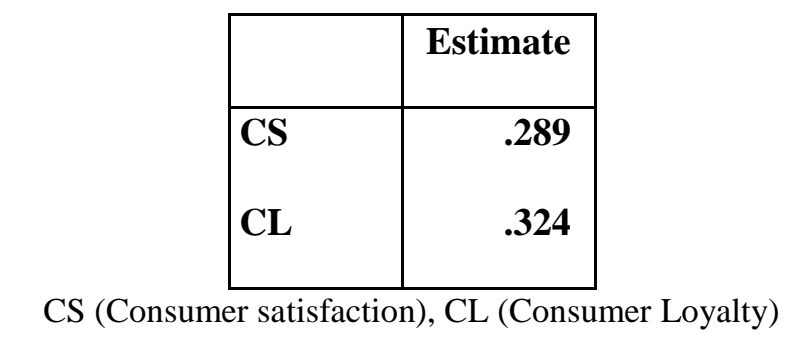

\section{Direct Influence Analysis}

From the table above, it can be seen that the significance value of all relationships is < 0.05 , and one effect is negative, namely the effect of perceived value on consumer satisfaction. So it can be said:

1. There is a significant and positive influence with a value of 0.157 Brand Image variable on Customer Satisfaction. In accordance with the research conducted by (Lasander, 2013), (Pramudyo, 2016), (Kurniawati, 2014).

2. There is a significant and negative influence with a value of 0.302 variable Price Perception on Consumer Satisfaction. According to research (Wariki et al., 2015), (Novrianda, 2018), (Pamungkas, 2019).

3. There is a significant and positive influence with a value of 0.516 of the value perception variable on consumer satisfaction. According to research (Soegoto, 2013), (Yamin, 2013), (Widjojo, 2013).

4. There is a significant and positive influence with a value of 0.098 of the Brand Image variable on Consumer Loyalty. According to research (Pramudyo, 2016), (Tomida \& Satrio, 2016), (N. K. Dewi \& SE, 2012).

5. There is a significant and positive influence with a value of 0.223 variable Price Perception on Consumer Loyalty. According to research (Budiastari, 2018), (P. S. A. Dewi \& Suprapti, 2018), (Wulandari et al., 2019).

6. There is a significant and positive influence with a value of 0.250 of the Value Perception variable on Consumer Loyalty. According to research (Soegoto, 2013), (Setiawan, 2016), (Ramdhani et al., 2015).

7. There is a significant and positive influence with a value of 0.205 for the variable Customer Satisfaction on Consumer Loyalty. According to research (Soegoto, 2013), (Setiawan, 2016), (Ramdhani et al., 2015).

In this section, it must answer the research problem or hypothesis that has been previously formulated.

From the Squared Multiple Correlations table or often referred to as the coefficient of determination, it can be explained that the variables of Brand Image, Price Perception and Value Perception are able to explain the variation of Customer Satisfaction by $28.9 \%$, and the 
variables Brand Image, Price Perception, Value Perception and Consumer Satisfaction are able to explain variations Consumer Loyalty of $32.4 \%$.

\section{Indirect Influence Analysis}

From calculations using Amos 12.0.0, the results for the indirect effect are as follows:

Table 5. Indirect Effects

\begin{tabular}{|c|cccc|}
\hline & PN & PH & CM & KK \\
\hline KK & .000 & .000 & .000 & .000 \\
LK & .106 & -.062 & .032 & .000 \\
\hline
\end{tabular}

Furthermore, to see whether the indirect effect is significant or not, the Sobel Test is used with the results :

Table 6. Sobel Test

\begin{tabular}{|l|r|r|}
\hline \multicolumn{2}{|c|}{ Pengaruh Tidak Langsung } & \multicolumn{1}{l|}{ Sobel Test } \\
\hline Citra Merek -> Kepuasan -> Loyalitas & 0,03219 & 2,81212963 \\
\hline Persepsi Harga -> Kepuasan -> Loyalitas & $-0,06191$ & $-2,11695797$ \\
\hline Persepsi Nilai -> Kepuasan -> Loyalitas & 0,10578 & 2,65906034 \\
\hline
\end{tabular}

From the Sobel test results, it can be concluded:

1. There is a significant and positive influence with a value of 0.032 in the Brand Image variable on Customer Loyalty through Customer Satisfaction. According to research (Pramudyo, 2016).

2. There is a significant and negative influence with a value of 0.062 variable Price Perception on Consumer Loyalty through Customer Satisfaction. According to research (Wariki et al., 2015).

3. There is a significant and positive influence with a value of 0.106. Value Perception variable on Customer Loyalty through Customer Satisfaction. According to research (Soegoto, 2013), (Setiawan, 2016), (Ramdhani et al., 2015). 
From the information above it can be concluded that all indirect effects on Customer Loyalty through Customer Satisfaction are significant.

As for the comparison between the direct effect and the indirect effect, we can conclude as follows:

1. The direct effect of brand image on consumer loyalty is 0.098 , which is greater than the indirect effect of brand image on consumer loyalty through customer satisfaction of 0.032 .

2. The direct effect of Price Perception on Consumer Loyalty is 0.223 greater than the indirect effect of Price Perception on Consumer Loyalty through Customer Satisfaction of -0.062 .

3. The direct effect of Value Perception on Consumer Loyalty is 0.250 greater than the indirect effect of Value Perception on Consumer Loyalty through Customer Satisfaction of 0.105 .

\section{CONCLUSION AND SUGESTION}

\section{Conclusion}

1. There is a significant influence of the variable brand image, perceived price, and perceived value on consumer satisfaction directly.

2. There is a significant effect of the variable brand image, perceived price, perceived value, and consumer satisfaction on direct consumer loyalty.

3. There is a significant influence of the variable brand image, price perception, perceived value on consumer loyalty through customer satisfaction.

4. Perception of price has a significant effect in a negative direction directly on customer satisfaction, which means that price increases can reduce customer satisfaction.

\section{Sugestion}

1. Rayhan Toko Muslim must be very concerned about the price, because it negatively affects customer satisfaction.

2. The brands that are being sold today, and the value provided by Rayhan Toko Muslim, have satisfied consumers, so that they are maintained and improved, so that consumer loyalty can be realized.

\section{REFERENCE}

Barnes, J. G. (2003). Secrets of Customer Relationship Management (Rahasia Manajemen Hubungan Pelanggan). Yogyakarta: Andi.

https://doi.org/10.1161/CIRCULATIONAHA.115.019645

Bernhard. (2006). Marketing (1st ed.). Pearson Education International.

Boyd, \& Lareche. (2000). Marketing (7th ed.). Prentice Hall Inc.

Budiastari, S. (2018). Pengaruh Kualitas Produk, Persepsi Harga, Dan Citra Merek Terhadap Kepuasan Dan Loyalitas Pelanggan Beton Siap Pakai Holcim Di Jakarta. Jurnal Dinamika 
Manajemen Dan Bisnis, 1(1), 87-106.

Dewi, N. K., \& SE, G. A. (2012). Pengaruh Iklan, Citra Merek, dan Kepuasan Konsumen

Terhadap Loyalitas Konsumen dalam Menggunakan Vaseline Hand and Body Lotion di

Kota Padang (Studi Kasus di PT. Unilever Cabang Padang). Sumber, 6(1), 26.

Dewi, P. S. A., \& Suprapti, N. W. S. (2018). Membangun Loyalitas Pelanggan melalui

Kepuasan yang Dipengaruhi oleh Kualitas Produk, Persepsi Harga, dan Citra Merek.

Matrik: Jurnal Manajemen, Strategi Bisnis, Dan Kewirausahaan, 12(2), 87-98.

Engel, J. F., Blackwell, R. D., \& Miniard, P. W. (2001). Perilaku Konsumen, Jilid 2. Jakarta:

Binarupa Aksara.

Ghozali, I. (2018). Aplikasi Analisis Multivariate dengan Program IBM SPSS. Yogyakarta:

Universitas Diponegoro. In (Edisi 9). Semarang: Badan Penerbit Universitas Diponegoro.

Griffin, A. (2002). Product development cycle time for business-to-business products.

Industrial Marketing Management. https://doi.org/10.1016/S0019-8501(01)00162-6

Hapzi Ali. Nandan Limakrisna. (2013). Metodologi Penelitian (Petunjuk Praktis Untuk

Pemecahan Masalah Bisnis, Penyusunan Skripsi, Tesis, dan Disertasi. In Deeppublish:

Yogyakarta. https://doi.org/10.1360/zd-2013-43-6-1064

Hasan, A. (2009). Marketing edisi baru. Yogyakarta: MedPress.

Kotabe, M., \& Murray, J. Y. (2004). Global sourcing strategy and sustainable competitive advantage. Industrial Marketing Management.

https://doi.org/10.1016/j.indmarman.2003.08.004

Kotler, P. and Keller, K. (2006). Marketing Management MARKETING MANAGEMENT

Marketing Management. In Marketing Management.

Kotler, Philip \& Amstrong, G. (2006). Principles of marketing (11 ed.). New York: Pearson

International.

Kotler, P., \& Keller, K. L. (2016). MarkKotler, P., \& Keller, K. L. (2016). Marketing

Management. Global Edition (Vol. 15E).

https://doi.org/10.1080/08911760903022556eting Management. In Global Edition.

https://doi.org/10.1080/08911760903022556

Kurniawati, D. (2014). Pengaruh Citra Merek dan Kualitas Produk terhadap Kepuasan dan

Loyalitas Pelanggan (Studi pada Pelanggan KFC Cabang Kawi Malang). Jurnal

Administrasi Bisnis, 14(2).

Lamb, C. W., Hair, J. F., \& McDaniel, C. (2011). Marketing. In Climate Change 2013 - The

Physical Science Basis.

Lasander, C. (2013). Citra merek, kualitas produk, dan promosi pengaruhnya terhadap

kepuasan konsumen pada makanan tradisional. Jurnal EMBA: Jurnal Riset Ekonomi,

Manajemen, Bisnis Dan Akuntansi, 1(3).

Lau, G. T., \& Lee, S. H. (1999). Consumers' Trust in a Brand and the Link to Brand Loyalty.

Journal of Market-Focused Management. https://doi.org/10.1023/A:1009886520142

Novrianda, H. (2018). Analisis pengaruh kualitas produk, kualitas layanan, dan harga terhadap

kepuasan konsumen. Performance: Jurnal Personalia, Financial, Operasional, Marketing

Dan Sistem Informasi, 25(2), 28-35.

Pamungkas, S. (2019). Pengaruh Kualitas Pelayanan dan Harga terhadap Kepuasan

Pelanggan pada Domino's Pizza Cabang Cimone Tangerang. 
Pramudyo, A. (2016). Pengaruh Citra Merek Terhadap Loyalitas Melalui Kepuasan Sebagai Intervening (Studi pada Mahasiswa Perguruan Tinggi Swasta di Yogyakarta). Jurnal Bisnis, Manajemen, Dan Akuntansi, 1(1).

Ramdhani, H. S., Daryanto, A., \& Rifin, A. (2015). Kepuasan sebagai Variabel antara Kualitas Produk, Kualitas Pelayanan, dan Persepsi Nilai terhadap Loyalitas Konsumen pada Restoran Baru. Jurnal Ilmu Keluarga \& Konsumen, 8(2), 115-124.

Saladin, D., \& Oesman, Y. M. (2003). Intisari Pemasaran dan Unsur-unsur Pemasaran. Cetakan Ketiga, Bandung: Linda Karya.

Schiffman, L. G., \& Kanuk, L. L. (2004). Cross-Cultural Consumer Behavior: An International Perspective. In Consumer Behavior. https://doi.org/10.1002/cpp.780

Sekaran, U., \& Bougie, R. (2011). Business Research Methods: A skill-building approach. In Wiley. https://doi.org/http://as.wiley.com/WileyCDA/WileyTitle/productCd-

111994225X.html\#

Setiawan, H. (2016). Pengaruh Kualitas Layanan, Persepsi Nilai dan Kepercayaan terhadap

Kepuasan dan Loyalitas Pengguna Layanan Mobile Banking. Jurnal Keuangan Dan Perbankan, 20(3), 518-528.

Simamora, B. (2002). Panduan riset perilaku konsumen. Gramedia Pustaka Utama.

Soegoto, A. S. (2013). Persepsi nilai dan kepercayaan terhadap kepuasan dan dampaknya terhadap loyalitas konsumen. Jurnal EMBA: Jurnal Riset Ekonomi, Manajemen, Bisnis Dan Akuntansi, 1(3).

Sugiyono, D. (2019). Statistika untuk Penelitian (Cetakan ke-30). In Bandung: CV ALFABETA. Tjiptono. (2008). Stratergi Pemasaran. In Edisi Kedua, Penerbit Andi,Yogyakarta.

Tomida, M., \& Satrio, B. (2016). Pengaruh harga dan citra merek terhadap loyalitas pelanggan produk Footwear Yongki Komaladi. Jurnal Ilmu Dan Riset Manajemen (JIRM), 5(7).

Wariki, G. M., Mananeke, L., \& Tawas, H. (2015). Pengaruh Bauran Promosi, Persepsi Harga Dan Lokasi Terhadap Keputusan Pembelian Dan Kepuasan Konsumen Pada Perumahan Tamansari Metropolitan Manado. Jurnal EMBA: Jurnal Riset Ekonomi, Manajemen, Bisnis Dan Akuntansi, 3(2).

Widjojo, P. O. (2013). Pengaruh Persepsi Nilai Pelanggan dan Kepuasan Konsumen Terhadap Loyalitas Konsumen Hypermart Pakuwon Trade Center di Surabaya. Kajian Ilmiah Mahasiswa Manajemen, 2(4).

Wulandari, O. A. D., Suroso, A., \& Setyanto, R. P. (2019). Pengaruh Citra Destinasi Dan Persepsi Harga Terhadap Loyalitas Pengunjung Di Owabong Melalui Kepuasan Sebagai Variabel Mediasi. Jurnal Ekonomi, Bisnis, Dan Akuntansi, 21(2).

Yamin, R. (2013). Persepsi Nilai, Persepsi Kualitas, dan Citra terhadap Kepuasan Konsumen pada PT. Astra International Daihatsu di Manado. Jurnal EMBA: Jurnal Riset Ekonomi, Manajemen, Bisnis Dan Akuntansi, 1(3).

Zeithaml, V. A. (1988). Consumer perceptions of price, quality, and value: a means-end model and synthesis of evidence. Journal of Marketing, 52(3), 2-22.

Zikmund, W. G. (2003). Business Research Methods / William G. Zikmund. South-Western Publishing. 